\title{
Insulin Sensitivity Modulates the Growth Response during the First Year of High-Dose Growth Hormone Treatment in Short Prepubertal Children Born Small for Gestational Age
}

\author{
Inge Gies ${ }^{a} \quad$ Muriel Thomas $^{j} \quad$ Sylvie Tenoutasse ${ }^{b} \quad$ Kathleen De Waele $^{d}$ \\ Marie-Christine Lebrethon ${ }^{g}$ Dominique Beckers ${ }^{\mathrm{h}}$ Inge François ${ }^{\mathrm{e}}$ Marc Maes $^{\mathrm{f}}$ \\ Raoul Rooman ${ }^{c}$ Carine de Beaufort ${ }^{k}$ Guy Massa ${ }^{i}$ Jean De Scheppera,d \\ Department of Pediatrics, University Hospital, at a Brussels (UZ Brussel), ${ }^{\mathrm{b}}$ Bruxelles (HUDERF), 'Antwerp (UZA), \\ ${ }^{\mathrm{d}}$ Ghent (UZ Gent), e Leuven (UZ Gasthuisberg), ${ }^{\mathrm{f}}$ Louvain (UCL), ${ }^{9}$ Liège (CHU), and ${ }^{\mathrm{h}}$ Mont-Godinne, and 'Department \\ of Pediatrics, Jessa Hospital, Hasselt, and jBelgian Study Group for Pediatric Endocrinology, Brussels, Belgium; \\ kDepartment of Pediatrics, Hospital of Luxembourg, Luxembourg, Luxembourg
}

\section{Key Words}

Insulin sensitivity · Growth • Growth hormone treatment •

Small for gestational age $\cdot$ Leptin

\begin{abstract}
Aim: To study the relationship between insulin sensitivity and growth response in short children born small for gestational age (SGA) treated with growth hormone (GH). Methods: Randomized, open-label, 24-month intervention study in 40 short prepubertal SGA children [age (mean \pm SD) 5.3 \pm 1.5 years], who either remained untreated $(n=20)$ or were treated with $\mathrm{GH}(66 \mu \mathrm{g} / \mathrm{kg} /$ day; $\mathrm{n}=20)$. Changes in fasting glucose, insulin, quantitative insulin sensitivity check index (QUICKI), IGF-1 and leptin after 1 and 2 years were studied. Results: Mean height SDS increased from $-3.3 \pm 0.7$ to -2.3 \pm 0.7 after 1 year, and to $-1.9 \pm 0.7$ after 2 years of treatment. QUICKI decreased significantly $(p=0.008)$ in the first year of GH treatment and stabilized in the second year. Baseline QUICKI was positively associated $(r=0.40 ; p<0.05)$ with
\end{abstract}

\section{KARGER}

Fax +4161306 1234

E-Mail karger@karger.ch

www.karger.com
(C) 2012 S. Karger AG, Basel

$1663-2818 / 12 / 0781-0024 \$ 38.00 / 0$

Accessible online at:

www.karger.com/hrp the change in height SDS in the first year. Conclusion: Higher insulin sensitivity at the start of GH therapy is associated with greater first-year growth response to $\mathrm{GH}$, and could be a promising parameter in selecting prepubertal short SGA children for $\mathrm{GH}$ treatment. However, this finding needs to be confirmed in larger studies.

Copyright $\odot 2012$ S. Karger AG, Basel

\section{Introduction}

During the first 2 years of life, the majority of children born small for gestational age (SGA) present catch-up growth in weight and length $[1,2]$. Increased insulin secretion has been linked to patterns of this rapid postnatal catch-up in length of SGA infants [3]. On the other hand,

This work was supported by a grant from the Foundation of the Belgian Study Group for Pediatric Endocrinology. 
reduced insulin sensitivity has been a frequent finding in SGA children remaining short after infancy $[4,5]$.

It is well established that daily administration of recombinant growth hormone $(\mathrm{GH})$ promotes a significant gain in body height and weight in short SGA children [6, 7]. The short-term responses to GH therapy are highly variable: in several studies a threefold variation in the first-year height SDS increase could be observed [7, 8]. Furthermore, the early changes in stature were found to diminish or stabilize in the subsequent years of continued GH therapy, despite the fact that the circulating IGF1 concentrations during GH therapy remain elevated or even increase [9].

On the other hand, an impairment of the insulin sensitivity with a two- to threefold increase of both fasting and stimulated insulin concentrations during the first years of GH treatment have been observed in short prepubertal SGA children [10,11]. We hypothesized that a greater growth response to $\mathrm{GH}$ might be found in those SGA children with higher insulin sensitivity at the start. Therefore, in this study we analyzed insulin sensitivity (from measurements of fasting glucose and insulin) at baseline, and after 1 and 2 years of GH therapy. We additionally measured fasting leptin and IGF-1 concentrations since both have been related to $\mathrm{GH}$ responsiveness and catch-up growth in SGA children $[12,13]$.

\section{Methods}

\section{Patients}

Forty children were recruited from the departments of pediatric endocrinology of 8 Belgian hospitals and one Luxembourgian hospital according to the following inclusion criteria: (1) birth weight and/or length below -2 SD for gestational age; (2) current height below $-2.5 \mathrm{SD}$; (3) height velocity below $+1.0 \mathrm{SD}$ (measurements of height at time of inclusion and $12 \pm 6$ months earlier), and (4) ages between 3 and 8 years at the start of the study. Exclusion criteria were: (1) prematurity (gestational age below 34 weeks); (2) endocrine disease including GH deficiency, bone disease or any severe chronic disease; (3) Turner, Noonan or Down syndrome, or other chromosomal abnormalities; (4) current or previous irradiation therapy, current or previous (12 \pm 6 months before inclusion) treatment with oral steroids for more than 3 months, and (5) severe mental retardation. Twenty-two females and 18 males were included. The clinical characteristics of the included patients are summarized in table 1 .

\section{Study Protocol}

After stratification by the minimization method for gender, chronological age, weight SDS and hospital, the children were allocated to either a GH-treated $(\mathrm{n}=20)$ or untreated group $(\mathrm{n}=$ 20).

Insulin Sensitivity and Growth Response
The treated children received recombinant human $\mathrm{GH}$ for 2 years from the start of the study. The dose of GH (Genotonorm, Pfizer, USA) was $66 \mu \mathrm{g} / \mathrm{kg}$ body weight per day. The dose was adjusted to body weight every 6 months. The untreated group was followed over 2 years without receiving GH therapy with the opportunity to start GH treatment for a period of 2 years afterwards. The local ethics committees of the participating centers approved the study and informed consent was obtained from the parents.

\section{Measurements}

Assessments of body height, weight and insulin sensitivity were performed at baseline and after 1 and 2 years. Measurements of standing body height and body weight as well as assessment of pubertal development were performed at the local hospital by one trained observer. Body height and weight were expressed as SD score for chronological age and sex (SDS) [14]. BMI was calculated and expressed as SDS [14]. Pubertal stages were scored according to Tanner $[15,16]$.

Blood samples were collected in fasting condition at baseline and after 1 and 2 years of treatment. Glucose was measured locally within $2 \mathrm{~h}$ after collection and serum was stored for centralized analysis of insulin, IGF-1 and leptin. Insulin sensitivity was estimated by the quantitative insulin sensitivity check index (QUICKI), using the fasting plasma glucose and serum insulin concentrations [17].

Changes in height SDS score between start and 1 year and between 1 and 2 years were calculated for each subject as the measure of variation in growth response to $\mathrm{GH}$. The first-year change in height SDS was chosen as a parameter for the growth-promoting effect of $\mathrm{GH}$ and the second-year change as a measure for the waning effect of GH therapy.

\section{Laboratory Assays}

Plasma glucose concentration was measured by the glucose oxidase method on an automated analyzer. Serum insulin was measured by a commercial IRMA (Bi-Insulin IRMA 2009, CisBio International, Gif-sur-Yvette, France). The cross-reactivity was $<0.0001 \%$ with proinsulin and the detection limit was 0.5 $\mathrm{mU} / \mathrm{l}$; the intra- and interassay coefficient of variation were 3.8 and less than $8 \%$, respectively. Serum IGF-1 was measured by a commercial radioimmunoassay (DSL-5600 ACTIVE) and the detection limit was $0.8 \mathrm{ng} / \mathrm{ml}$; the intra- and interassay coefficients were 3.7 and $1.5 \%$. Reference data provided by the manufacturer were used for the calculation of IGF-1 z-scores. Serum leptin was measured with a commercial IRMA (DSL-23100) and the detection limit was $0.1 \mathrm{ng} / \mathrm{ml}$; the intra- and interassay coefficients were 3.9 and $6.7 \%$.

\section{Statistical Analysis}

Results are shown as means and SD. First-year changes were calculated as the value at 1 year minus the baseline value, and second-year changes as the value at 2 years minus the first-year value. To adjust for the baseline values, percent changes [(actual value - baseline value/baseline value) $\times 100$ ] in QUICKI, IGF-1 and leptin at 1 and 2 years were calculated. Differences between groups were assessed by a mixed between-within ANOVA. Pearson's correlations coefficients were obtained to evaluate the relationship between quantitative variables. For statistical purposes, an extreme baseline QUICKI and IGF-1 and change in QUICKI 
Table 1. Body height, weight and BMI (SDS) at baseline and follow-up in the GH-treated and untreated groups

\begin{tabular}{|c|c|c|c|c|c|}
\hline & & Pre-GH & 1 year & 2 years & $\begin{array}{l}\text { GLM within subject } \\
\text { p value }\end{array}$ \\
\hline $\begin{array}{l}\text { GH-treated } \\
n=20(10 \text { males })\end{array}$ & $\begin{array}{l}\text { Age, years } \\
\text { Height, cm } \\
\text { Height SDS } \\
\text { Weight, kg } \\
\text { Weight SDS } \\
\text { BMI } \\
\text { BMI SDS } \\
\text { Height velocity, cm/year }\end{array}$ & $\begin{array}{r}5.6 \pm 1.6^{\mathrm{a}} \\
97.0 \pm 9.9^{\mathrm{a}} \\
-3.3 \pm 0.7^{\mathrm{a}} \\
13.0 \pm 3.1^{\mathrm{a}} \\
-3.8 \pm 1.3^{\mathrm{a}} \\
13.7 \pm 1.3^{\mathrm{a}} \\
-1.7 \pm 1.1 \\
5.2 \pm 1.3^{\mathrm{a}}\end{array}$ & $\begin{array}{r}6.6 \pm 1.7^{\mathrm{b}} \\
107.1 \pm 9.5^{\mathrm{b}} \\
-2.3 \pm 0.7^{\mathrm{b}} \\
15.8 \pm 3.7^{\mathrm{b}} \\
-2.8 \pm 1.3^{\mathrm{b}} \\
13.8 \pm 1.5^{\mathrm{b}} \\
-1.6 \pm 1.3 \\
9.8 \pm 1.4^{\mathrm{b}}\end{array}$ & $\begin{array}{r}7.5 \pm 1.7^{\mathrm{c}} \\
114.5 \pm 9.8^{\mathrm{c}} \\
-1.9 \pm 0.7^{\mathrm{c}} \\
18.5 \pm 4.3^{\mathrm{c}} \\
-2.3 \pm 1.2^{\mathrm{c}} \\
13.9 \pm 1.3^{\mathrm{c}} \\
-1.5 \pm 1.1^{\mathrm{e}} \\
7.7 \pm 1.2^{\mathrm{c}}\end{array}$ & $\begin{array}{c}<0.0001 \\
<0.0001 \\
<0.0001 \\
<0.0001 \\
<0.0001 \\
0.157 \\
0.024 \\
<0.0001\end{array}$ \\
\hline $\begin{array}{l}\text { Untreated } \\
\mathrm{n}=20 \text { (8 males })\end{array}$ & $\begin{array}{l}\text { Age, years } \\
\text { Height, cm } \\
\text { Height SDS } \\
\text { Weight, kg } \\
\text { Weight SDS } \\
\text { BMI } \\
\text { BMI SDS } \\
\text { Height velocity, cm/year }\end{array}$ & $\begin{array}{r}5.1 \pm 1.3^{\mathrm{a}} \\
95.1 \pm 7.4^{\mathrm{a}} \\
-3.2 \pm 0.9^{\mathrm{d}} \\
12.3 \pm 2.5^{\mathrm{a}} \\
-3.9 \pm 1.4 \\
13.5 \pm 1.3^{\mathrm{a}} \\
-2.0 \pm 1.5 \\
5.7 \pm 1.2\end{array}$ & $\begin{array}{c}6.1 \pm 1.3^{\mathrm{b}} \\
100.8 \pm 7.2^{\mathrm{b}} \\
-3.1 \pm 0.9 \\
13.8 \pm 2.7^{\mathrm{b}} \\
-3.8 \pm 1.4 \\
13.5 \pm 1.4^{\mathrm{b}} \\
-2.0 \pm 1.5 \\
5.6 \pm 0.8\end{array}$ & $\begin{array}{r}7.1 \pm 1.3^{\mathrm{c}} \\
106.2 \pm 7.2^{\mathrm{c}} \\
-3.1 \pm 0.9^{\mathrm{e}} \\
15.4 \pm 2.9^{\mathrm{c}} \\
-3.7 \pm 1.5^{\mathrm{e}} \\
13.5 \pm 1.4^{\mathrm{c}} \\
-2.0 \pm 1.5 \\
5.4 \pm 0.9\end{array}$ & $\begin{array}{c}<0.0001 \\
<0.0001 \\
0.013 \\
<0.0001 \\
0.15 \\
0.978 \\
0.876 \\
0.673\end{array}$ \\
\hline
\end{tabular}

${ }^{\mathrm{a}} \mathrm{p}<0.0001$ after paired $\mathrm{t}$ test between pre-GH and 1 year. ${ }^{\mathrm{b}} \mathrm{p}<0.0001$ after paired $\mathrm{t}$ test between 1 year and 2 years. ${ }^{\mathrm{c}} \mathrm{p}<0.0001$ after paired t test between pre-GH and 2 years. ${ }^{\mathrm{d}} \mathrm{p}<0.05$ after paired t test between pre-GH and 1 year. ${ }^{\mathrm{e}} \mathrm{p}<0.05$ after paired test between pre-GH and 2 years.

GLM = General linear model.

and IGF-1 values were excluded in the calculation of the regression coefficients. Percent of variance in changes in QUICKI during the first year and second year were calculated as the coefficient of determination [(square of Pearson's correlation coefficient $) \times 100]$. Multiple regression and forward step regression analysis models for each of the studied hormonal parameters were used in the selection of the predictors of the change in height SDS.

\section{Results}

\section{Baseline Levels and Evolution of Growth Parameters}

As shown in table 1, there were no significant differences between the two study groups for any of the baseline growth variables, including growth velocity, which was within normal age limits in all subjects. One child in the treated group dropped out of the study after 1 year because of refusal of further injections. Height velocity almost doubled during the first year of GH therapy (5.2 \pm 1.3 vs. $9.8 \pm 1.4 \mathrm{~cm} /$ year), while it did not change in the untreated group. In the treated group, height velocity decreased significantly during the second year $(9.8 \pm 1.4$ vs. $7.7 \pm 1.2 \mathrm{~cm} /$ year), but remained significantly higher compared to the untreated group $(7.7 \pm 1.2$ vs. $5.4 \pm 0.9$ $\mathrm{cm} /$ year). Weight gain during the first year averaged 2.9 $\pm 0.8 \mathrm{~kg}$ in treated children and was twice as high $(\mathrm{p}<$ $0.0001)$ as in the untreated children $(1.4 \pm 0.5 \mathrm{~kg})$. Weight gain in the second year was slightly lower than during the first year of treatment $(2.6 \pm 0.7 \mathrm{~kg})$, but remained higher than in the untreated group.

The accelerated growth in the GH-treated group induced major changes in height SDS: mean height SDS increased from $-3.3 \pm 0.7$ to $-2.3 \pm 0.7$ after 1 year and to $-1.9 \pm 0.7$ after 2 years. A great variability in the growth response was observed in the treated patients: the change in height SDS ranged between 0.38 and 1.80 in the first year and between -0.29 and 0.86 in the second year. BMI SDS remained unchanged over the 2 -year observation period in the treated and untreated group. None of the participating children entered puberty during the course of the study.

\section{Baseline Levels and Evolution of Hormonal Parameters}

Annual results of the longitudinal follow-up of fasting glucose, insulin, leptin and IGF-1 and the calculated QUICKI are shown in table 2. At baseline there were no differences between the two groups. Serum IGF-1 tripled 
Table 2. Biological data of both groups at baseline and follow-up

\begin{tabular}{|c|c|c|c|c|c|}
\hline & & Pre-GH & 1 year & 2 years & $\begin{array}{l}\text { GLM within subject } \\
\text { p value }\end{array}$ \\
\hline $\begin{array}{l}\text { GH treated } \\
n=20(10 \text { males })\end{array}$ & $\begin{array}{l}\text { Glucose, } \mathrm{mg} / \mathrm{dl} \\
\text { Insulin, } \mu \mathrm{U} / \mathrm{ml} \\
\text { IGF-1, } \mu \mathrm{g} / \mathrm{l} \\
\text { IGF-1 SDS } \\
\text { Leptin, } \mu \mathrm{g} / \mathrm{l} \\
\text { QUICKI }\end{array}$ & $\begin{array}{c}79 \pm 12 \\
3.0 \pm 1.8^{\mathrm{a}} \\
97 \pm 91.8^{\mathrm{a}} \\
-1.6 \pm 0.7^{\mathrm{a}} \\
1.5 \pm 0.9^{\mathrm{d}} \\
0.446 \pm 0.061^{\mathrm{d}}\end{array}$ & $\begin{array}{c}81 \pm 9 \\
5.3 \pm 2.1 \\
306.4 \pm 120.8^{\mathrm{e}} \\
0.46 \pm 1.0 \\
1.1 \pm 1.1^{\mathrm{b}} \\
0.391 \pm 0.046\end{array}$ & $\begin{array}{c}80 \pm 10^{\mathrm{f}} \\
5.5 \pm 2.9^{\mathrm{f}} \\
389.4 \pm 204^{\mathrm{c}} \\
0.9 \pm 1.8^{\mathrm{c}} \\
4.4 \pm 2.2^{\mathrm{c}} \\
0.392 \pm 0.042^{\mathrm{f}}\end{array}$ & $\begin{aligned} & 0.748 \\
& 0.003 \\
< & 0.0001 \\
< & 0.0001 \\
< & 0.0001 \\
& 0.033\end{aligned}$ \\
\hline $\begin{array}{l}\text { Untreated } \\
\mathrm{n}=20 \text { (8 males })\end{array}$ & $\begin{array}{l}\text { Glucose, } \mathrm{mg} / \mathrm{dl} \\
\text { Insulin, } \mu \mathrm{U} / \mathrm{ml} \\
\text { IGF-1, } \mu \mathrm{g} / \mathrm{l} \\
\text { IGF-1 SDS } \\
\text { Leptin, } \mu \mathrm{g} / 1 \\
\text { QUICKI }\end{array}$ & $\begin{array}{c}76 \pm 9 \\
2.9 \pm 1.9 \\
79.6 \pm 52.7 \\
-1.7 \pm 0.6 \\
2.0 \pm 1.5 \\
0.439 \pm 0.047\end{array}$ & $\begin{array}{c}79 \pm 12^{\mathrm{e}} \\
3.3 \pm 1.9 \\
97.4 \pm 56^{\mathrm{e}} \\
-1.6 \pm 0.6^{\mathrm{e}} \\
2.2 \pm 2.2^{\mathrm{e}} \\
0.429 \pm 0.055\end{array}$ & $\begin{array}{c}79 \pm 9^{\mathrm{f}} \\
3.5 \pm 1.7 \\
167.2 \pm 108.8^{\mathrm{c}} \\
-1.1 \pm 1.18^{\mathrm{f}} \\
4.9 \pm 3.1^{\mathrm{f}} \\
0.420 \pm 0.043\end{array}$ & $\begin{array}{c}0.344 \\
0.672 \\
<0.0001 \\
0.004 \\
0.004 \\
0.546\end{array}$ \\
\hline
\end{tabular}

${ }^{\mathrm{a}} \mathrm{p}<0.0001$ after paired t test between pre-GH and 1 year. ${ }^{\mathrm{b}} \mathrm{p}<0.0001$ after paired t test between 1 year and 2 years. ${ }^{\mathrm{c}} \mathrm{p}<0.0001$ after paired t test between pre-GH and 2 years. ${ }^{\mathrm{d}} \mathrm{p}<0.05$ after paired $\mathrm{t}$ test between pre-GH and 1 year. ${ }^{\mathrm{e}} \mathrm{p}<0.05$ after paired $\mathrm{t}$ test between 1 year and 2 years. ${ }^{\mathrm{f}} \mathrm{p}<0.05$ after paired test between pre-GH and 2 years.

$\mathrm{GLM}=$ General linear model.

Table 3. Correlations between the changes in height SDS and hormonal parameters at baseline and their changes during the first year of treatment

\begin{tabular}{lll}
\hline & \multicolumn{2}{c}{ Delta height SDS $0-1$ year } \\
\cline { 2 - 3 } & $\mathrm{R}$ & $\mathrm{p}$ value \\
\hline Age & -0.62 & 0.003 \\
IGF-1 & -0.41 & 0.031 \\
Leptin & -0.09 & 0.710 \\
Insulin & -0.43 & 0.063 \\
QUICKI & 0.40 & 0.040 \\
Delta IGF-1 & 0.47 & 0.040 \\
Delta IGF-1, \% & 0.68 & 0.001 \\
Delta leptin & 0.06 & 0.804 \\
Delta leptin, \% & -0.26 & 0.30 \\
Delta QUICKI & -0.48 & 0.040 \\
Delta QUICKI, \% & -0.36 & 0.137 \\
\hline
\end{tabular}

during the first year of GH therapy ( $\mathrm{p}<0.0001)$, while a smaller increase in the second year of treatment was observed. Serum leptin concentration during GH treatment showed a biphasic pattern: a significant $(\mathrm{p}<0.005)$ decrease in the first year (from $1.5 \pm 0.9$ to $1.1 \pm 1.13 \mu \mathrm{g} / \mathrm{l}$ ), followed by a significant $(\mathrm{p}<0.0001)$ increase in the second year (to $4.4 \pm 2.2 \mu \mathrm{g} / \mathrm{l}$ ). The fasting insulin concentration almost doubled in the first year $(p<0.0001)$, and remained at a similar level in the second year. QUICKI decreased significantly $(\mathrm{p}<0.05)$ during the first year of GH therapy and subsequently stabilized in the second year, but remained unchanged in the control group during the whole observation period.

Baseline QUICKI was unrelated to BMI SDS and birth weight SDS in the treated group, but correlated negatively with age $(r=-0.39 ; p<0.005)$, parental adjusted height deficit $(r=-0.33 ; p<0.05)$, leptin concentration $(r=$ -0.38 ; $p<0.05)$, IGF- 1 concentration $(r=-0.41 ; p<0.05)$ and change in QUICKI in the first year $(\mathrm{r}=-0.78$; $\mathrm{p}<$ 0.0005).

\section{Associations between Growth Response and Baseline Hormonal Parameters}

As shown in table 3, in the GH-treated group baseline IGF-1 was negatively associated with the change in height SDS in the first year $(r=-0.41 ; \mathrm{p}<0.05)$, whereas pretreatment QUICKI was positively associated $(\mathrm{r}=0.40$; $\mathrm{p}<0.05)$. The correlation between baseline QUICKI and the first-year growth response persisted after correction for age and IGF-1 $(r=0.36 ; p=0.07)$. Using stepwise multiple regression analysis including age, baseline IGF-1 and baseline QUICKI, the first-year change in height SDS was best determined by the pretreatment QUICKI: change in height SDS $=-0.54+3.31 \times$ QUICKI $(r=0.64$; $\mathrm{p}<0.005)$ when outliners were included (fig. 1); and by 


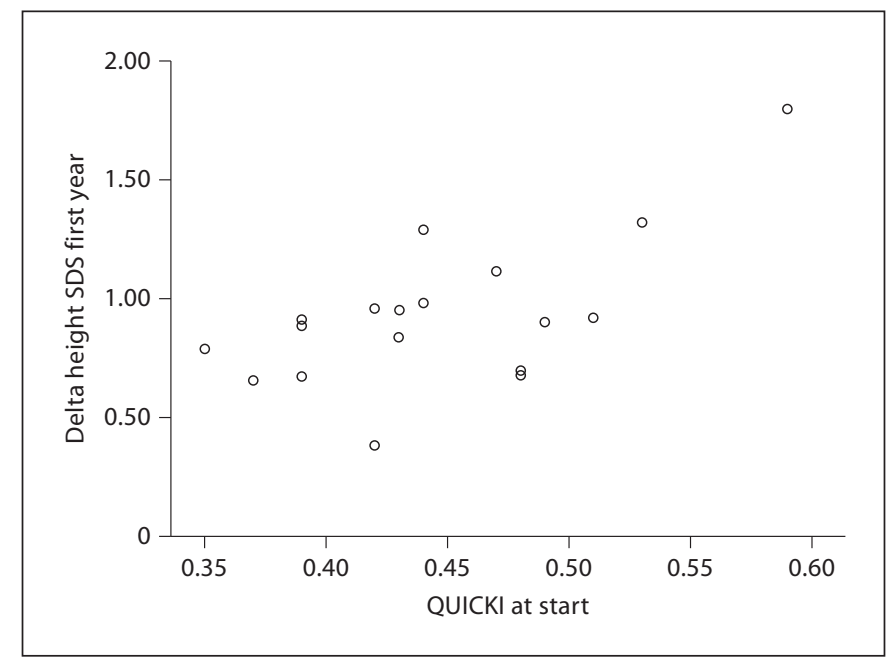

Fig. 1. Scatterplot of QUICKI at the start and change in height SDS in the first year of treatment.

age if outliners were excluded: change in height SDS = $1.29-0.70 \times$ age (years) $(r=0.46 ; p<0.05)$. The 1-year values of all the studied hormonal parameters were unrelated to the change in height SDS in the second year.

\section{Associations between Growth Response and Changes in Hormonal Parameters}

As shown in table 3, the change in height SDS in the first year was negatively correlated with the absolute change in QUICKI ( $\mathrm{r}=-0.48 ; \mathrm{p}<0.05)$, also after correction for age and baseline IGF-1 $(r=-0.42 ; p=0.07)$, but not with the percent QUICKI increase. On the other hand, both the absolute and the percent change in serum IGF-1 correlated significantly with the first-year height gain. The changes in height SDS during the second year correlated positively with the absolute and percent changes in QUICKI observed in the second year $(\mathrm{r}=0.60$; $\mathrm{p}<$ 0.005 and $\mathrm{r}=0.53 ; \mathrm{p}<0.05$, respectively).

\section{Discussion}

Daily administration of high-dose GH in short prepubertal SGA children was found to induce profound catchup growth in the first year: a doubling of growth velocity and body weight gain in the first year compared to a control group was observed. The growth response to GH therapy, when expressed as change in height SDS, was similar to this observed in previous reports using a similar dose regimen in patient populations with a compa- rable age range [6]. Both the child's age and the administered GH dose are the prime variables related to the growth response over the first year $[8,9,18]$. In several, but not all studies, the growth response was, as in our study, related to the parental adjusted height deficit; however, in all studies its amplitude and interindividual variability decreased during the second year $[6,7,9]$.

Since clinical predictors have been shown to explain only a low percentage of this variability in previous studies, potential biochemical predictors of the growth response have been investigated $[18,19]$. In this study, we evaluated in particular whether the amplitude of the growth response to $\mathrm{GH}$ was associated with pretreatment values or changes in fasting insulin, IGF-1 and leptin, which have been shown to change significantly during GH therapy and have a possible impact on body growth $[9,13,20-22]$. Data on the fasting leptin concentration at the start of GH therapy in relation to the first-year growth response to $\mathrm{GH}$ are conflicting, which might be explained either by differences in GH dosing or the pretreatment nutritional status of the subjects between studies $[10,13$, 22]. Serum leptin concentration measured at the start was unrelated to the growth response in our subjects, who presented with a rather low BMI SDS. In all studies, including the present study, the most significant changes in leptin concentrations were observed in the first year of therapy and were found to be independent of the changes in BMI. We found, in accordance with a previous study, that the gain in height SDS during the first year on GH was negatively related to pretreatment serum IGF-1 [23]. Serum IGF-1 concentration has been suggested to be a better marker of endogenous somatotropic axis activity, which in contrast to stimulated peak GH levels, might better predict the first-year growth response to $\mathrm{GH}$ in SGA children [9].

In our study, QUICKI, known to be a simple and validated parameter for insulin sensitivity in prepubertal children, was also found to be an important predictor for the first-year growth response [24]. Although there is a general agreement that the euglycemic hyperinsulinemic clamp technique is the best available standard for the measurement of insulin action, it is hardly applicable in young tiny SGA children and especially in longitudinal intervention studies. QUICKI has been shown to be a useful screening test for insulin resistance in prepubertal children and is probably a better parameter of insulin sensitivity than fasting insulin concentration since it better reflects the known hyperbolic relationship between insulin sensitivity and insulin production, and has better repeatability characteristics $[25,26]$. 
An important finding of our study was that pretreatment QUICKI as well as the absolute decrease in QUICKI during the first year determined the magnitude of the height gain during the first year of GH therapy, whereby a higher baseline QUICKI and a more severe decrease in QUICKI favored a better growth response. This means that children with the highest insulin sensitivity at baseline, who developed a higher degree of insulin resistance during treatment, were the best responders to $\mathrm{GH}$ treatment. On the other hand, part of the correlations on reduction in insulin sensitivity might be explained by the phenomenon of regression to the mean.

Our findings are in contrast with the findings of an Australian and a German study, where no correlation between the degree of fall in insulin sensitivity and the growth acceleration during GH therapy was found in short SGA children $[10,11]$. The validity of these studies, however, can be questioned since prepubertal as well as pubertal subjects, who have different degrees of insulin sensitivity, were included. Furthermore, in the Australian study, subjects with very low insulin sensitivity were included, and insulin sensitivity was assessed after a variable duration of GH therapy. We observed in a properly performed longitudinal study using 12 months of timed QUICKI measurements that the insulin sensitivity might differ in the same subject, depending on changes in BMI SDS and IGF-1 concentrations. We found a mean decrease in QUICKI of $10 \%$ in the first 12 months, with serum IGF-1 levels explaining $30 \%$ of this variance. In fact, the elevation of circulating $\mathrm{GH}$ levels can mediate the reduction in insulin sensitivity. The mechanism of this $\mathrm{GH}$-induced reduction in insulin sensitivity involves multiple sites in insulin receptor signal transduction [27]. GH may also reduce insulin sensitivity by increasing lipolysis and circulating free fatty acid levels [28].

Although it is unknown whether the association between the increase in insulin resistance and the early growth response is coincidental or causal in nature, similar conditions of accelerated growth, elevated GH secretion and increased insulin resistance are observed during infancy in the majority of SGA children with spontaneous catch-up growth. A similar condition also occurs during puberty in normal children. The compensatory hyperinsulinism can be hypothesized as a common underlying factor for this association between accelerated growth and increased insulin resistance [12, 29]. Using mouse metatarsal bone growth plated in culture, insulin was shown to stimulate metatarsal linear growth and the heights of the epiphyseal, proliferative and hypertrophic zones in a concentration-dependent fashion [30]. It re- mains to be established whether insulin acts in its growth stimulation activities via its own receptors, the IGF-1 receptors or the hybrid IGF-1/insulin receptor [31]. We observed in our study a negative correlation between the changes in growth and insulin sensitivity during the second year of treatment. In view of the present observations, we propose the following hypothesis: while the prevailing insulin sensitivity before GH therapy permits a better growth response through the $\mathrm{GH}$-induced compensatory hyperinsulinism initially, this insulin-mediated growth response can only be maintained during the course of GH therapy in those subjects showing some recuperation of the impaired insulin resistance.

One major practical application emerges from our findings: QUICKI could be taken into account to select the best candidates for GH therapy. However, future studies should be performed to determine whether our observations can be confirmed in larger studies since the origin of the growth retardation in SGA children is heterogeneous and our study population is rather small. Furthermore, the observed QUICKI results might be insulin assay-dependent, since insulin measurements depend on the type of assay used (with the newer IRMA assays showing a lowering of $20 \%$ compared to the RIA assays) and the cross-reactivity with proinsulin (in some assays, proinsulin accounts for $15-20 \%$ of the total amount of the fasting insulin) $[32,33]$.

In summary, we found that insulin sensitivity is an important determinant of the growth response to $\mathrm{GH}$ therapy, is associated with IGF-1 status, and decreases significantly during the first year of GH therapy in prepubertal short SGA children. Confirmation of our findings in a larger study is needed in order to determine the exact role of QUICKI in the selection of short prepubertal SGA children as candidates for high-dose GH therapy.

\footnotetext{
References

1 Leger J, Limoni C, Czernichow R: Prediction of the outcome of growth at 2 years of age in neonates with intra-uterine growth retardation. Early Hum Dev 1997;48:211-223.

2 Albertsson-Wikland K, Wennergren G, Wennergren M, Vilbergsson G, Rosberg S: Longitudinal follow-up of growth in children born small for gestational age. Acta Paediatr 1993;82:438-443.

-3 Soto N, Bazaes RA, Pena V, Salazar T, Avila A, Iniguez G, Ong K, Dunger D, Mericc M: Insulin sensitivity and secretion are related to catch-up growth in small-for-gestationalage infants at age 1 year: results from a prospective cohort. J Clin Endocrinol Metab 2003;88:3645-3650.
} 
4 Veening MA, Van Weissenbruch MM, Delemarre-Van De Waal HA: Glucose tolerance, insulin sensitivity, and insulin secretion in children born small for gestational age. J Clin Endocrinol Metab 2002;87:4657-4661.

5 Woods KA, van Helvoirt M, Ong KK, Mohn A, Levy J, de Zegher F, Dunger D: The somatotropic axis in short children born small for gestational age: relation to insulin resistance. Pediatr Res 2002;51:76-80.

6 Fjellestad-Paulsen A, Czernichow P, Brauner R, Bost M, Colle M, Lebouc JY, Lecornu M, Leheup B, Limal J, Raux M, Toublanc J, Rappaport R: Three-year data from a comparative study with recombinant human growth hormone in the treatment of short stature in young children with intrauterine growth retardation. Acta Paediatr 1998;87:511-517.

7 Chatelain P, Job J, Blanchard J, Ducret JP, Olver M, Sagnard L, VanderschuerenLodeweyckx M: Dose-dependent catch-up growth after 2 years of growth hormone treatment in intrauterine growth-retarded children. Belgian and French Pediatric Clinics and Sanofi-Choay (France). J Clin Endocrinol Metab 1994;78:1454-1460.

$\checkmark 8$ de Zegher F, Albertsson-Wikland K, Wollmann HA, Chatelain P, Chaussain JL, Löfström A, Jonsson B, Rosenfeld R: Growth hormone treatment of short children born small for gestational age: growth responses with continuous and discontinuous regimens over 6 years. J Clin Endocrinol Metab 2000;85:2816-2821.

-9 Sas T, de Waal W, Mulder P, Houdijk M, Jansen $M$, Reeser $M$, Hokken-Koelega A: Growth hormone treatment in children with short stature born small for gestational age: 5 -year results of a randomized, doubleblind, dose-response trial. J Clin Endocrinol Metab 1999;84:3064-3070.

-10 Cutfield W, Jackson W, Jefferies C, Robinson E, Breier B, Richards G, Hofman P: Reduced insulin sensitivity during growth hormone therapy for short children born small for gestational age. J Pediatr 2003;142:113-1136.

-11 Bachmann S, Bechtold S, Bonfig W, Putzker S, Buckl M, Schwarz HP: Insulin sensitivity decreases in short children born small for gestational age treated with growth hormone. J Pediatr 2009;154:509-513.

$\checkmark 12$ Ong K, Kratzsch J, Kiess W, Dunger D, ALSPAC Study Team: Circulating IGF-I levels in childhood are related to both current body composition and early postnatal growth rate. J Clin Endocrinol Metab 2002;87:10411044.
13 Boguszewski M, de Zegher F, AlberssonWikland K, Nordic Study Group for Growth Hormone Treatment in SGA Children and the Belgian Study Group for Pediatric Endocrinology: Serum leptin in short children born small for gestational age: dose-dependent effect of growth hormone treatment. Horm Res 2000;54:120-125.

14 Cole T, Freeman J, Preece M: Body mass index reference curves for the UK, 1990. Arch Dis Child 1995;73:25-29.

15 Marshall W, Tanner J: Variations in pattern of pubertal changes in girls. Arch Dis Child 1969;44:291-303.

16 Marshall W, Tanner J: Variations in pattern of pubertal changes in boys. Arch Dis Child 1970;45:13-23.

17 Katz A, Nambi S, Mather K, Baron A, Follmann D, Sullivan G, Quon M: Quantitative insulin sensitivity check index: a simple, accurate method for assessing insulin sensitivity in humans. J Clin Endocrinol Metab 2000;85:2402-2410.

18 Ranke M, Lindberg A, Cowell C, Wikland K, Reiter E, Wilton P, Price D, KIGS International Board: Prediction of response to growth hormone treatment in short children born small for gestational age: analysis of data from KIGS (Pharmacia International Growth Database). J Clin Endocrinol Metab 2003;88:125-131.

19 Rapaport R, Saenger P, Wajnrajch M, Pfizer SGA Collaborative Study Group: Predictors of first-year growth response to a fixed-dose growth hormone treatment in children born small for gestational age: results of an openlabel, multicenter trial in the United States. J Pediatr Endocrinol Metab 2008;21:411422.

20 Bannink E, van Doorn J, Mulder P, Hokken-Koelega A: Free/dissociable insulin-like growth factor (IGF)-I, not total IGF-I, correlates with growth response during growth hormone treatment in children born small for gestational age. J Clin Endocrinol Metab 2007;92:2992-3000.

21 Cutfield W, Lundgren F: Insulin-like growth factor I and growth responses during the first year of growth hormone treatment in KIGS patients with idiopathic growth hormone deficiency, acquired growth hormone deficiency, Turner syndrome and born small for gestational age. Horm Res 2009;71(suppl 1):39-45.

22 Lebl J, Lebenthal Y, Kolouskova S, Steensberg A, Jons K, Kappelgaard A, Ibanez L, Philip M: Metabolic impact of growth hormone treatment in short children born small for gestational age. Horm Res Paediatr 2011; 76:254-261.
23 de Zegher F, Ong K, van Helvoirt M, Mohn A, Woods K, Dunger D: High-dose growth hormone $(\mathrm{GH})$ treatment in non-GH-deficient children born small for gestational age induces growth responses related to pretreatment GH secretion and associated with a reversible decrease in insulin sensitivity. J Clin Endocrinol Metab 2002;87:148-151.

24 Uwaifo G, Fallon E, Chin J, Elberg J, Parikh $S$, Yanovski J: Indices of insulin action, disposal, and secretion derived from fasting samples and clamps in normal glucose-tolerant black and white children. Diabetes Care 2002;25:2081-2087.

25 Gungor N, Saad R, Janosky J, Arslaninan S: Validation of surrogate estimates of insulin sensitivity and insulin secretion in children and adolescents. J Pediatr 2004;144:47-55.

26 Mather K, Hunt A, Steinberg H, Paradisi G, Hook G, Katz A, Quon M, Baron A: Repeatability characteristics of simple indices of insulin resistance: implications for research applications. J Clin Endocrinol Metab 2001; 86:5457-5464.

27 Smith T, Elmendorf J, David T, Turinsky J: Growth hormone-induced insulin resistance: role of the insulin receptor, IRS-1, GLUT-1, and GLUT-4. Am J Physiol 1997; 272:E1071-E1079.

28 Piatti P, Monti L, Caumo A, Conti M, Magni F, Galli-Kienle M, Fochesato E, Pizzini A, Baldi L, Valsecchi G, Pontiroli A: Mediation of the hepatic effects of growth hormone by its lipolytic activity. J Clin Endocrinol Metab 1999;84:1658-1663.

29 Dunger D, Ong K: Endocrine and metabolic consequences of intrauterine growth retardation. Endocrinol Metab Clin North Am 2005;34:597-615.

$30 \mathrm{Wu}$ S, Aguilar A, Ostrow V, De Luca F: Insulin resistance secondary to a high-fat diet stimulates longitudinal bone growth and growth plate chondrogenesis in mice. Endocrinology 2011;152:468-475.

31 Laron Z: Insulin - a growth hormone. Arch Physiol Biochem 2008;114:11-16.

32 Reaven G, Chen Y, Hollenbeck C, Sheu W, Ostrega D, Polonsky K: Plasma insulin, Cpeptide, and proinsulin concentrations in obese and nonobese individuals with varying degrees of glucose tolerance. J Clin Endocrinol Metab 1993;76:44-48.

-33 Robbins D, Andersen L, Bowsher R, Chance R, Dinesen B, Frank B, Gingerick R, Goldstein D, Widemeyer H, Haffner S, Hales C, Jarett L, Polonsky K, Ponte D, Skyler J, Webb G, Gallagher K: Report of the American Diabetes Association's Task Force on Standardization of the Insulin Assay. Diabetes 1996; 45:242-256. 